\title{
Efficiency Measurement of Malaysian Agriculture Firms
}

\author{
Zarehan Selamat and Annuar Md Nasir
}

\begin{abstract}
The government's objectives for agricultural sector are to ensure food security, increase export earnings, and to improve productivity and competency. Given its importance role to the economy development, the present study aims to examine the efficiency and productivity level of selected agriculture firms in Malaysia. Precisely, this study will examine the efficiency of agricultural firms in Malaysia over the last 15 years period from 1995 to 2010 by using Data Envelopment Analysis (DEA). The results obtain from this study will help agriculture firms' management and policy makers to determine how successful the agriculture firms is, especially in achieving efficiency and productivity, make efficient production decisions and also to determine areas in which improvement is needed.
\end{abstract}

Index Terms-Efficiency, productivity, agriculture, data envelopment analysis, Malaysia.

\section{INTRODUCTION}

In the mid-1980s, policy makers, academics, and policy analysts appear to have lost interest on agriculture sector in which the importance of the agricultural sector declines with economic development. This mostly because of low prices in world markets for basic agricultural commodities. However, recently, there is renewed interest in this sector in the national development agenda. Malaysian government has put a greater important on agriculture and agro based sector in which this sector is given a new lease of life in order to become third engine of economic growth for country and to make the country self-sufficient in food. After about two decades of being neglected, interest in agriculture is returning. This is due to an understanding that growth in agricultural sectors plays an important role in the overall economic and development, particularly in making contributions to economic growth, foreign exchange earnings, employment, and supply of raw materials for agroand resource- based industry. The sector is also important as a provider of food and poverty reduction especially in rural area.

The renewed interest in agriculture is also linked to two major reasons. The first major reason is ensuring food security and reducing food import bill. The economic crisis $1997 / 1998$ had certainly raised everyone's awareness of the importance of agriculture and agro based industry in providing self-sufficiency in food production. A drastic change in the exchange rate of the ringgit during the crisis reinforced the above need as imported food items tend to be more costly. The total food import was RM4.6 billion in 1990, went up to RM10.0 billion in 1997 and RM13.0 billion in 2002 (MIER, 2002).

Manuscript received October 9, 2012; revised March 13, 2013.

Zarehan Selamat is with Multimedia University, Malaysia (e-mail: Zarehan.selamat@mmu.edu.my)
The second reasons for this return of interest in agriculture on the policy agenda of Malaysia relates to the establishment of trade liberalization. WTO had opened agricultural sector to further competition increasing globalisation brings together opportunities and challenges to the agricultural industries. Globalisation reduces the magnitude of tariff escalation and this in sequence offers easy market access for the agro based products of the developing countries.

Given its importance role to the economy development, policies and practices that promote growth and efficiency must be promoted while those that hinder progress must be discarded. Therefore, the main objective of the study is to analyse the efficiency of agriculture sector in Malaysia. In particular, this study will evaluate technical efficiency (EFFCH) and technological change (TECHCH) amongst selected agriculture based firms in Malaysia from 1995-2010.

The issue of efficiency and productivity of agriculture sector has been investigated in numerous studies for developed and developing countries. Among this research are studies by LeBel and Stuard (1998) in Canada, Yin (1998) in North America, Belen and Manuel (1997) in Spain, Battese and Coelli (1995) in India and Wadud and White (2000) in Bangladesh. However, the studies on efficiency and productivity have received very little attention in Malaysia. As of now, there is a dearth of empirical studies on the efficiency of Malaysian agriculture companies at either the national or regional. Hence, in this respect, the current study is expected to contribute information on performance of agriculture firms in Malaysia to literature, specifically in the context of a developing country.

The results obtain from this study will help agriculture firms' management and policy makers to determine how successful the agriculture firms is, especially in achieving efficiency and also to determine areas in which improvement is needed. A deeper understanding of the factors of sources of firm inefficiency will provide them with information that can be useful in the design of more effective policies to improve the performance of Malaysian agriculture sector.

\section{MAlaysia AgRiCUlture ECONOMIC DEVElOPMENT}

Presently manufacturing and service sectors are the two major pillars of the Malaysian economy. However, during its early history, economic activity is dominant by agriculture and mining sector. Agriculture sector has been significant contributor to the Malaysia economy, since it became independent in 1957. In 1960, agriculture contributed $38 \%$ to Gross Domestic Product (GDP) in contrast to the $9 \%$ of manufacturing sector. However, since the mid-1980s, the importance of agricultural sector and its contribution to the GDP has declined significantly with economic development and structural changes in the Malaysian economy. The declining trend in the relative importance of the agricultural 
sector is due to slow growth in commodity production and fluctuations in agricultural commodity prices. The government's industrialization strategy has also resulted in stronger growth in the other sectors especially manufacturing, services and petroleum.

In 2000 , its contribution accounted for $8.9 \%$ of the country GDP. In 2005, agriculture's share of GDP was declined to $8.2 \%$ (DOSM, 2005). However, total agriculture value added increased from RM18.7 billion in 2000 to RM21.6 billion in 2005 (Table 1.0). On the same time the value added of agro-based industry grew at an average rate of $4.5 \%$ per annum to reach RM16.9 billion in 2005 and contribute to increase in total GDP of the economy. The combined value added of the agriculture and agriculture based industry was RM38.5 billion or $14.7 \%$ of GDP in 2005. Total agricultural and agro-based export earnings also increased by an average rate of $9.5 \%$ per annum. The agriculture sector accounted for almost $60 \%$ of total employment in 1960. In 2000 and 2005, its share in employment dropped to 15.3 and 12.9 percent, respectively Though, labour productivity improved, as reflected by the increase in value added per worker from $\mathrm{RM} 13,120$ in 2000 to RM15,750 in 2005, at an average rate of $3.7 \%$ per annum.

The agriculture sector will continue to play a major role to the country's economic development in Malaysia. It was one of the highlighted issues during Tun Abdullah Ahmad Badawi's tenure as Malaysia's Prime Minister. Abdullah strongly believed that this industry can generate wealth and reduce poverty particularly among those from rural areas.

\begin{tabular}{|c|c|c|c|c|c|c|c|}
\hline \multirow[t]{2}{*}{ Commodity } & \multicolumn{3}{|c|}{$\begin{array}{c}\text { RM million } \\
\text { (in } 1987 \text { prices) }\end{array}$} & \multicolumn{3}{|c|}{$\%$ of Total } & \multirow{2}{*}{$\begin{array}{l}\text { Average } \\
\text { Growth } \\
\text { Rate }(\%)\end{array}$} \\
\hline & 2000 & 2005 & 2010 & 2000 & 2005 & 2010 & \\
\hline Agriculture & 18,662 & 21,585 & 27,517 & 100.0 & 100.0 & 100.0 & 3.0 \\
\hline $\begin{array}{l}\text { Industrial Commodities } \\
\text { Inte }\end{array}$ & $\begin{array}{l}18,602 \\
11,033\end{array}$ & $\begin{array}{l}13,278 \\
13,278\end{array}$ & 15,521 & 59.1 & 60.6 & $\begin{array}{r}10.0 \\
56.4\end{array}$ & 3.8 \\
\hline $\begin{array}{l}\text { Oil Palm } \\
\text { Palutes }\end{array}$ & $\begin{aligned} 3,860 \\
5,860\end{aligned}$ & 7,915 & $\begin{array}{l}10,068 \\
10,068\end{array}$ & 31.4 & 36.7 & $\begin{array}{l}36.4 \\
36.6\end{array}$ & $\begin{array}{l}.00 \\
6.2\end{array}$ \\
\hline Forestry and Logging & 3,055 & 3,016 & 2,761 & $\begin{array}{l}16.4 \\
16.4\end{array}$ & 13.0 & 10.0 & -0.3 \\
\hline Rubber & 1,868 & 2,264 & 2,554 & 10.0 & 10.5 & 9.3 & 3.9 \\
\hline Cocoa & 250 & 83 & 138 & 1.3 & 0.4 & 0.5 & -19.8 \\
\hline Food Commodities & 7,629 & 8,308 & 11,996 & 40.9 & 39.4 & 43.6 & 1.7 \\
\hline Fisheries & 2,493 & 2,389 & 3,875 & 13.4 & 12.6 & 14.1 & -0.9 \\
\hline Livestock & 1,520 & 2,089 & 2,483 & 8.1 & 8.1 & 9.0 & 6.6 \\
\hline & 590 & 632 & 988 & 3.2 & 3.4 & 3.6 & 1.4 \\
\hline 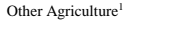 & 3,026 & 3,198 & 4,650 & 16.2 & 15.2 & 16.9 & 1.1 \\
\hline Agro-Based Industry & 13,584 & 16,928 & 22,221 & 100.0 & 100.0 & 100.0 & 4.5 \\
\hline $\begin{array}{l}\text { Vege and Animals Oils \& } \\
\text { Fats }\end{array}$ & 2,526 & 3,639 & 5,614 & 18.6 & 21.5 & 25.3 & 7.6 \\
\hline $\begin{array}{l}\text { Other Food Processing, } \\
\text { Beverages \& Tobacco }\end{array}$ & 1,520 & 4,790 & 6,333 & 29.5 & 28.3 & 28.5 & 3.6 \\
\hline $\begin{array}{l}\text { Wood Products including } \\
\text { Furniture }\end{array}$ & 2,934 & 2,972 & 3,761 & 21.6 & 17.6 & 16.9 & 0.3 \\
\hline $\begin{array}{l}\text { Paper \& Paper Products, } \\
\text { Printing \& Publishing }\end{array}$ & 2,293 & 2,640 & 3,275 & 16.9 & 15.6 & 14.7 & 2.9 \\
\hline $\begin{array}{l}\text { Rubber Processing \& } \\
\text { Products }\end{array}$ & 1,821 & 2,887 & 3,238 & 13.4 & 17.1 & 14.6 & 9.7 \\
\hline $\begin{array}{l}\text { Total Agriculture \& } \\
\text { Agro-Based Industry }\end{array}$ & 32,246 & 38,513 & 49,738 & & & & 3.6 \\
\hline $\begin{array}{l}\text { Gross Domestic Product } \\
\text { at Purchasers' Price }\end{array}$ & 210,558 & 262,029 & 351,297 & & & & 4.5 \\
\hline
\end{tabular}

Since Independence, agricultural development has been influenced by twelve Five Year National Economic Development Plans.

- The First Malaya Plan, 1956-1960

- The Second Malaya Plan, 1961-1965

- The First Malaysia Plan, 1966- 1970

- The Second Malaysia Plan, 1971- 1975

- The Third Malaysia Plan, 1976-1980

- The Fourth Malaysia Plan, 1981-1985

- The Fifth Malaysia Plan, 1986-1990

- The Sixth Malaysia Plan, 1991-1995
- The Seventh Malaysia Plan, 1996-2000

- The Eighth Malaysia Plan, 2001-2005

- The Ninth Malaysia Plan, 2006-2010

- The Tenth Malaysian Plan, 2011-2015

The key objectives of development in the agricultural sector outlined in all the plans include the following:-

- to address the concerns regarding food security i.e. to ensure that there is adequate supply of food from domestic sources so as to reduce reliance on imported food

- to play a dynamic role in the export-led economic growth strategy

- poverty eradication amongst the agricultural workers.

In order, to achieve efficient implementation of agricultural development in the context of Five Year National Economic Development Plans, the Government introduced three National Agricultural Policies (NAP).

The First National Agricultural Policy (NAP1) was in promulgated in 1984. This era saw a rapid expansion of the manufacturing sector, altering the relative importance of the agricultural sector in economy. The overall development of the agricultural sector during this period was surrounded with problems, including labor shortages, rising wages, and increasing competition of land for other uses. The NAP1 (1984-1991) formulation was to ensure balanced and sustained rate of growth as in the other sectors of the economy. The objective was to maximize income from agriculture through the efficient and effective use of the country's resources and to enhance the sector's contribution to the overall economic growth of the nation. The policy aims to combine small size farms into mini estates to redistribute rural land and to attain economies of scale by increasing production

The Second National Agricultural Policy (NAP2) was introduced after NAP 1 was reviewed. NAP 2 covers the period 1991-2010 which aims for a "market-led, commercialized, competitive, efficient, and dynamic agricultural sector within the context of sustainable development. The greater emphasis was given to address efficiency and productivity of agricultural enterprises based on rapid innovations in products and processes and expanded use of latest technologies. The policy outlines strategies for expanding food production, a greater role for the private sector, marketing reforms and accelerating agriculturally based industrial development. In addition to that, NAP2 was drafted in line with other policies such as World Trade Organization (WTO), Asean Free Trade Area (AFTA) and Asia-Pacific Economic Cooperation (APEC).

NAP3 was drafted to overcome the 1997 financial crisis that is to find alternatives and solution for manufacturing sector. The primary objectives of NAP3 is increasing exports and reducing the imports of agricultural commodities is in the meeting the challenge of enhance and more efficient agricultural production. More specifically, the objectives of NAP3 are, to enhance food security; to increase productivity and competitiveness of the agricultural sector; to strengthen linkages with other sectors particularly the agro-based industry and the related services sector; to explore and develop new sources of growth; and adopting sustainable 
development and to reduce trade deficit in food.

Agricultural development is also implemented in the context of the New Economic Policy (NEP). During the implementation of NEP, from 1970 to 1990, the objective of all the agricultural policies was to increase agriculture production to meet national requirements, to create employment and to raise income. This was in line with the NEP objectives of reducing poverty and restructuring of the society. Furthermore, the production of agriculture is very important as food security and in trade balance. Excessive dependence on imports will put this country in critical condition if there are incidents affecting the production in the supplying countries. National Development Policy (NDP) 1991-2000 was then implemented as a continuity of NEP because of its significant impact in national development.

\section{LITERATURE REVIEW}

Fried, Lovell, and Schmidt (1993) defined efficiency of production as a comparison between observed and optimal value of its output and inputs. It is the ability to produce the maximum output with the given input or using minimum input for given output with the given technology. It is an indication of whether the firms are able to use the current technology in the best way. Efficiency measurement can be used as guidance for planning and development decisions. Efficiency in production will enable firms to face successfully any future changes in the supply management system. Firms is said to be efficient if they can fully export the best available technology and therefore lie on the frontier of the technology. Any deviation from the best technology resulted in inefficiency. When firms are efficient they incur lower cost of production, improved quality of products and hence higher profits. Such an efficient firm can only be competitive in the domestic as well as global market.

The literature on the measurement of efficiency begins with Farrel (1957) with his seminal paper entitled "The Measurement of Productive Efficiency". Since then, a variety of efficiency measures to evaluate the performance of decision making units have been developed in the literature. Farrell (1957) proposed that the efficiency of any given firm consisted of two components: Technical efficiency (TE) (sometimes referred to a pure technical efficiency) and allocative efficiency (AE) (also called price efficiency). The first measure may be conducted in terms of quantities (inputs or outputs), and the second refers to values (cost, revenue and profit).

Technical efficiency (TE) is associated with the production of output(s) given some input(s) in which a production plan is defined as technically efficient, if there is no way of producing more output(s) with the same input(s). Technical efficiency depicts whether a production unit is using the best available technology. Thus, it measures the position of the production unit relative to the production frontier. As with these definitions, technical efficiency is based on the frontier production function, which shows whether a firm is able to attain the maximum potential output from a given set of inputs and technology (Aigner et al., 1977). Firm level technical efficiency in a given industry is measured relative to the best performing firms in that industry. When a firm is technically efficient, the maximum output is generated from a given level of output. The deviation from efficiency production frontier is considered technical inefficiency. A firm is assumed to be technically inefficient if excessive usage of resources is needed in relative to its level of production (Cummins and Weiss, 1993). Technical efficiency further categorized into scale efficiency and pure technical efficiency (Fukuyama, 1993).

Pure technical efficiency is concerns about the optimal use of resources. When a firm is assuming not operating at an optimal scale, variable return to scale (VRS) assumption is imposed and the result obtained is termed as pure technical efficiency (Worthington and Hurley 2002). Pure technical efficiency reflects the extent to which a firm can decrease its inputs within the VRS with notation of fixed proportion of inputs (Diacon et al., 2002). To simplify, it is the comparison between the ratio of outputs to inputs under observation with those achieved by the best practice unit on the ground of management coordination (Abbott and $\mathrm{Wu}, 2002$ ).

On the other hand, scale efficiency is a measure of the effectiveness of the size of an operating unit and reflects potential productivity gain from achieving optimal size (Coelli et al. 1998). Scale efficiency, identifies whether the firm operates at an optimal or sub-optimal size and come in three forms: increasing return to scale (IRS), decreasing return to scale (DRS), or constant returns to scale (CRS). It is based on whether the changes in production (output) are proportionally more than, less than, or equal to the proportional changes in inputs. CRS implies that proportional increase in the amounts of inputs results in an equal proportional increase in the amount of output. For example, if the inputs values for a unit are 10 percent increase, then the unit must produce an equal 10 percent increase in production. Alternatively, operating at an inappropriate size may raise the issue of scale inefficiency. Scale inefficiency is the extent to which a firm is expected by the difference of return to scale, either increasing or decreasing. Increasing return to scale (IRS) and decreasing return to scale (DRS) implies that a change in the amount of inputs results in a proportionately greater than and smaller than the proportionate increase in outputs.

The second dimension of efficiency is allocative or price efficiency. In production theory, allocative efficiency conventionally reflects the ability of the firm to use inputs in optimal combinations, for given input prices to produce a certain level of output. The allocative measurement requires information on prices. An allocatively efficient firm would produce that output using the lowest cost combination of inputs. Combining the technical efficiency (TE) and allocative efficiency (AE) provide a measure of total or economic efficiency. Economic efficiency is the ability of company to produces a certain level of output at the lowest feasible costs; costs may arise above the lowest possible level due to lack of either technical or allocative efficiency.

There has been an extensive body of empirical research on the economic efficiency of farmers in both developed and developing countries (for review see Battese, 1992 and Coelli, 1995). A number of studies have focused on estimation of efficiency and the potential to improve the productivity of agricultural production in developing 
agriculture. For example; India (Battese and Coelli 1995), Bangladesh (Wadud and White 2000), China (Coelli and Rao 2005, Weining and Won (1997), Philippines (Fulgini and Perrin,1997; Umetsu, Lekprichakul and Chakravorty, 2003), and Vietnam (Nghiem and Coelli (2002). Despite the extensive body of literature dealing with agriculture in developing country, the study about Malaysian agriculture is still rare and has not received attention in the published literature.

In Malaysia, TPF studies seem to center on time series analysis of productivity growth in the manufacturing sector. Rauzah (2000) examined the productive or technical efficiency of 29 sub-sector of the Malaysian manufacturing sector. She utilized the stochastic frontier production function by using panel data. The findings shows that firms tend to improve their technical efficiency over time. For instance, the sub sectors with high values of average technical efficiency such as petroleum refineries, petroleum and coal products, industrial chemicals, beverages, tobacco and nonmetallic mineral have relatively high values for labour productivity and capital intensity.

Mahadevan (2011) uses the stochastic frontier approach examines the two sources of total factor productivity growth (TFP), namely technological progress (TP) and technical efficiency (TE) in the Malaysian manufacturing sector. The result indicates that TFP growth was found to be below 1.5 per cent over 1970-2002, and while TE was negative, TP although positive was decreasing over time. Factor accumulation resulted in some TP but this was at the expense of TE.

There has been no prior study on the efficiency of agriculture at the firm level. Against his back drop the motivation of this paper is to investigate the efficiency of agriculture firms in Malaysia using the non-parametric approach.

\section{RESEARCh DESIGN AND MEthodology}

In order to examine technical efficiency of the agricultural firms, this study applies Data Envelopment Analysis (DEA). According to Charnes et al., (1978), DEA is a non-parametric linear programming for the development of production frontiers and the measurement of efficiency relative to the developed frontiers. The advantage of DEA method is that it allows efficiency to be measured with no pre- specification of a functional form and distributional form for the different inputs and outputs used. DEA can accommodate multiple inputs and outputs and does not require input or output prices in order to identify the best practice production frontier. DEA also is less data demanding than econometrics methods because it does not require a large sample of size. It works well with small sample size and does not require knowledge of the proper functional forms (Grifell-Tatje and Lovell, 1996).

DEA can be either input-orientated or output-orientated. DEA method defines the frontier by seeking the maximum possible proportional reduction in input usage, with output levels held constant, for each country. While, in the output orientated case, the DEA method seeks the maximum proportional increase in output production, with input levels held fixed. According to Coelli et al. (2005) input and output orientation should be chosen based on whether the managers have most control over inputs or outputs. This is because in some industries firms have specific orders to fill and hence the input quantities are the primary decision variable. In other industries, firms may be required to produce as much as possible with given quantities of resources.

In this study, we use a Malmquist index approach to examine intercompany agricultural efficiency. The reason is because out of the three methods, Malmquist index has certain advantages over the other two. Grifell and Lovel (1996) indicated that Malmquist Index has three main advantages relative to Fisher and Tornqvist indices. 1) it does not require the profit maximization, or the cost minimization assumption, 2) it does not require input and output prices and it is possible to calculate productivity only with information on quantity, 3) if the researcher has panel data, the Malmquist approach can distinguish between two sources of productivity growth, technical efficiency change or catching up index and technical changes or the change in the best practice index (Fare et al, 1994). Malmquist index major drawback is the necessity to compute the distance functions. However, linear programming technique of the DEA technique can be used to solve this problem.

The Malmquist productivity index, as presented by Fare $e t$ al. (1994), is linked with the use of distance functions. Distance functions allow one to describe a multi-input, multi-output production technology without the involvement of explicit price data and the need to specify a behavioural objective such as cost minimisation or profit maximisation. Distance functions are classified into input distance functions and output distance functions. An input distance function characterises the production technology by looking at a minimum proportional contraction of the input vector, given an output vector. An output distance function considers a maximum proportional expansion of the output vector, given an input vector (Fare et al., 1994).

Consider a unit in two periods $t$ and $t+1$, latter being the most recent period. Assume that for each period $t=1,2, \ldots, T$. Let $x t$ represent the input vector, and yt represent the output vector. The Malmquist productivity index between period $t$ and $(t+1)$ can be defined as

$$
M_{0}^{t+1}\left(x^{t+1}, y^{t+1}, x^{t}, y^{t}\right)=\left[\frac{D_{0}^{t}\left(x^{t+1}, y^{t+1}\right)}{D_{0}^{t}\left(x^{t}, y^{t}\right)} \frac{D_{0}^{t+1}\left(x^{t+1}, y^{t+1}\right.}{D_{0}^{t+1}\left(x^{t}, y^{t}\right)}\right]^{1 / 2}
$$

where $D$ represents the inverse of the distance function introduced by Caves et al. (1982). M is the geometric mean of two ratios of input inverse distance functions. The first ratio represents the period t Malmquist productivity index; it gives a measure of productivity change from period $t$ to period $(t+$ 1) using period t technology as a benchmark. The distance function in the numerator $D_{0}^{t}\left(x^{t+1}, y^{t+1}\right)$, measures the maximal proportional change in output required to make $\left(x^{t+1}, y^{t+1}\right)$ feasible in relation to the technology in period t. $D_{0}^{t}\left(x^{t}, y^{t}\right)$, the distance function in the denominator $D_{0}^{t}\left(x^{t}, y^{t}\right)$, measures the reciprocal of the maximum proportional expansion of the output vector given input vector. The second ratio is the period $(\mathrm{t}+1)$ 
Malmquist productivity index and gives a measure of productivity change from period $t$ to period $(t+1)$ using $(t+$ 1) technology as a benchmark. The distance function in the denominator $D_{0}^{t+1}\left(x^{t}, y^{t}\right)$, measures the maximal proportional change in output required to make $\left(x^{t}, y^{t}\right)$ feasible in relation to the technology period $(t+1)$, whereas the distance function in the numerator $D_{0}^{t+1}\left(x^{t+1}, y^{t+1}\right)$, measures the reciprocal of the maximum proportional expansion of the output vector $y^{t+1}$ given $x^{t+1}$. A value of $\mathrm{M}>1$ will indicate positive TFP growth, means that $(\mathrm{t}+1)$ productivity is greater than period $t$ productivity, whilst a value of $M<1$ indicate productivity decline because output is below the production frontier. $M=1$ means no change in productivity from time $t$ to $(t+1)$.

A useful feature of the Malmquist productivity index, first noted by Fare at al. (1985), is that it can be decomposed into the product of an index of technical efficiency change $(\mathrm{EFCH})$ and technical change (TCH). EFCH measures the catching-up effect, or change in performance of the firm to the best practice frontier by comparing technical efficiency measure in period $t+1$ with that in period $t$. In other words, it is the ratio of the index indicating how far the region is away from the technological frontier in period $t+1$ compared with the same ratio in period $t$. The technical change (TCH) captures the change in production technology as a shift in the production frontier. This measures the boundary shift in the sample wide technology between period $t$ and $t+1$. It is an indicator of the distance covered by the efficient frontier from one period to another and thus a measure of technological improvement between two periods. Thus, equation (1) is written as follows:

$M_{0}^{t+1}\left(x^{t+1}, y^{t+1}, x^{t}, y^{t}\right)=\frac{D_{0}^{t+1}\left(x^{t+1}, y^{t+1}\right)}{D_{0}^{t}\left(x^{t}, y^{t}\right)}\left[\frac{D_{0}^{t}\left(x^{t+1}, y^{t+1}\right)}{D_{0}^{t}\left(x^{t}, y^{t}\right)} \frac{D_{0}^{t+1}\left(x^{t+1}, y^{t+1}\right.}{D_{0}^{t+1}\left(x^{t}, y^{t}\right)}\right]^{1 / 2}$

where efficiency change $(\mathrm{EFCH})=\frac{D_{0}^{t+1}\left(x^{t+1}, y^{t+1}\right)}{D_{0}^{t}\left(x^{t}, y^{t}\right)}$

and technical change $(\mathrm{TCH})=\left[\frac{D_{0}^{t}\left(x^{t+1}, y^{t+1}\right)}{D_{0}^{t}\left(x^{t}, y^{t}\right)} \frac{D_{0}^{t+1}\left(x^{t+1}, y^{t+1}\right.}{D_{0}^{t+1}\left(x^{t}, y^{t}\right)}\right]^{1 / 2}$

As a result, the total productivity growth, $M$ is the product of $\mathrm{EFCH}$ and $\mathrm{TCH}: \quad \mathrm{M}=\mathrm{EFCH} \times \mathrm{TCH}$

Improvements in efficiency occur if $\mathrm{EFCH}>1$ and technical advances occur if $\mathrm{TCH}>1$. If the index is one, it implies that the firm has not improved its position with respect to the (moving) best practice frontier between the two periods. If it is less than one, the firm is falling behind the frontier (deterioration in performance).

Fare et al. (1994) showed that the efficiency change $(\mathrm{EFCH})$ component of the index can be separated into pure efficiency change (PCH) component and the scale efficiency change component $(\mathrm{SCH}) . \mathrm{PCH}$ measures the change in relative efficiency (i.e. the change in how far observed production is from the real maximum potential production) between times $t$ and $t+1$. $\mathrm{SCH}$ are changes in scale efficiency between times $\mathrm{t}$ and $t+1$ respectively (see Simar and Wilson (1998).
In particular:

$$
\begin{gathered}
\mathrm{PCH}=\frac{D_{0}^{t+1}\left(x^{t+1}, y^{t+1} \mid V R S\right)}{D_{0}^{t}\left(x^{t}, y^{t} \mid V R S\right)} \\
\text { and } \mathrm{SCH}=\left[\frac{D_{0}^{t}\left(x^{t+1}, y^{t+1} \mid V R S\right)}{D_{0}^{t}\left(x^{t}, y^{t}\right)} \frac{D_{0}^{t+1}\left(x^{t+1}, y^{t+1}\right.}{D_{0}^{t+1}\left(x^{t}, y^{t}\right) \mid V R S}\right]^{1 / 2}
\end{gathered}
$$

where VRS is variable returns to scale and $D$ (O|VRS) indicated distance functions calculated under the assumption of variable returns to scale. Values of $\mathrm{SCH}>1$ indicate that the operating unit has become more scale efficient.

Data

To measure the efficiency of agriculture sector in Malaysia, this study will analyses 100 agriculture based firms in Malaysia. To evaluate the effectiveness of overall performance of the agriculture programmes, the data of the study will cover the period of 1995 to 2010 . The data for the sample to be analyse was primarily derived from the respective companies' Annual Report for fifteen-years period since 1995.

\section{Determining the Input and Output Measures}

Efficiency can be defined as the extent to which a decision-making unit (DMU) can increase its outputs without increasing its inputs, or reduce its inputs without reducing its outputs. A DMU 'decides' how input can be transformed into output. The amount of input required and the amount of output produced may vary for each DMU. Each DMU is assigned an efficiency score that ranges between 0 and 1 , with a score equal to 1 indicating an efficient DMU with respect to the rest DMUs in the sample.

The inputs are resources or factors (e.g., labor, person or hours, capital, physical or human, materials, fertilizer or pesticide, utilities, energy, electricity, gas and fuel, etc) that the company uses to generates outputs (i.e., products and services) that are meant to be delivered to their users (i.e., intermediate and final customers). The output represents the return or outcomes that the company generates from the process, such as profit.

To evaluate technical efficiency and productivity the input values employed in this study are:

- Labour: In this study labour is used as cost of labour. Total cost of labour is the sum of salary and wages, contribution for benefit plan and other employee welfare.

- Operating Costs: The operating costs represent the day-to-day expenses incurred in running a business, such as sales and administration expenses. The costs are expressed in monetary terms.

- Capital: Capital is defined as the net value of Fixed Asset. Thus in this study, capital is refer to sum of net value of machinery and equipment and other capital assets which in turn, were calculated as a sum of beginning and ending inventories divided by two. All capital assets are measured on a cost basis.

Output measures used are: (a) turnover, and (b) net income. Turnover is the total value of the sales. The turnover captures the ability of the firm to sell its products and also indirectly reflects the market share of the firm compared with other firms. Net income is the turnover minus the expenses, interest and taxes. Net income captures the ability of the firm 
to make profits. Turnover and net income reflect the performance of the firm from the perspective of marketing and finance. That is, given the set of inputs, what proportion of the market the firm could capture and how much money could the firm make.

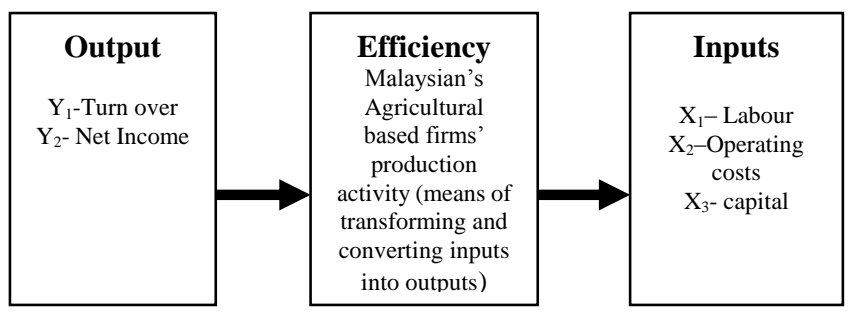

Fig. 1. Schematic diagram of input and output measures of an agriculture firm assessment

\section{CONCLUSION}

In conclusion, this study intends to analyse the efficiency of agriculture sector in Malaysia. In particular, this study plans evaluate technical efficiency $(\mathrm{EFFCH})$ and technological change (TECHCH) amongst selected agriculture firms in malaysia and to identify the determinants factors contributing to efficiency of agriculture sector at the firm level. In order to achieve the objectives of the study, this study applies the most commonly used non-parametric approach, namely Data Envelopment Analysis (DEA). An agriculture firm is considered efficient if it possible to reduce the amount of resources (input) it consumes yet it generates the same amount of output or it is possible to generate more output using the same amount of input. Later, the findings may be able to help firm managers to come up with adequate responses for improving and maintaining efficiency. For government, an awareness of determinants of agriculture efficiency may help them in designing policies and to determine how successful the policy is, especially in achieving efficiency, productivity, and financial performance of agriculture firms. In addition, these study also useful as a basis for future research of agriculture firms in Malaysia. The research can be provided by using different model or using other measure of firm's efficiency.

\section{REFERENCES}

[1] Malaysian Institute of Economic Research. (2002). An Uphill Task for Agriculture. [Online]. Available: http://www.mier.org.my/mierscope/musalmah3_8_2002.pdf

[2] L. Bel, L. G., and W. B. Stuard, "Technical Efficiency Evaluation of Logging Contractors using a Nonparametric Model," International Journal of Forest Engineering, vol. 9, pp. 15-24, 1998.

[3] R. Yin, "DEA: A New Methodology for Evaluating Performance of Forest Products Producer," Forest Production Journal, vol. 48, no. 1 , pp. 29-34, 1998.

[4] I. A. Belen and R. G. Manual, "Technical Efficiency in the Spanish Agrofood Industry, Agricultural Economic," Elsevier Science Limited, vol. 17, no. 2-3, pp. 179-189, 1997.

[5] G. E. Battese and T. J. Coelli, "A Model for Technical Inefficiency Effects in a Stochastic Frontier Production Function for Panel Data," Empirical Economics, vol. 20, pp. 325-332, 1995.

[6] A. Wadud and B. White, "Farm Household Efficiency in Bangladesh: A Comparison of Stochastic Frontier and DEA methods," Applied Economic, vol. 32, pp. 1665-1673, 2000.

[7] Annual National Account, Gross Domestic Product (GDP) 1987-2004, Department of Statistics, Malaysia, 2005.
[8] H. Fried, C. Lovell, and S. Schmidt, The Measurement of Productive Efficiency, New York Oxford University Press, 2003.

[9] M. J. Farrel, "The Measurement of Productive Efficiency," Journal of Royal Statistical Society, Series A, General, vol. 120, pp. 253-281, 1957.

[10] D. J. Aigner, C. A. K. Lovell, and P. Schmidt, "Formulation and Estimation of Stochastic Frontier Production Function Models," Journal of Econometrics, vol. 6, pp. 21-37, 1977.

[11] J. D. Cummins and M. A. Weiss, "Measuring Cost Efficiency in the Property-Liability Insurance Industry," Journal of Banking and Finance, vol. 17, pp. 463-81, 1993.

[12] H. Fukuyama, "Technical and Scale Efficiency of Japanese Commercial Banks: A Non Parametric Approach," Applied Economics, vol. 25 , pp. 1101-1112, 1993.

[13] A. C. Worthington and E. V. Hurley, "Cost Efficiency in Australian general Insurers: A Non parametric Approach," British Accounting Review, vol. 34, pp. 89-108, 2002.

[14] S. R. Diacon, K. Starkey, and C. O'Brien, "Size and Efficiency in European Long Term Insurance Companies: An International Comparison," Geneva Paper on Risk and Insurance, vol. 27, pp. 444-446, 2002.

[15] M. Abbot and S. Wu, "Total Factor Productivity and Efficiency of Australian Airports," Australian Economic Review, vol. 35, pp. 244-260, 2002.

[16] T. J. Coelli, P. Rao, and G. E. Battese, "An Introduction to Efficiency and Productivity Analysis," Boston: Kluwer Academic Publishers, 1998.

[17] G. E. Battese, "Frontier Production Functions and Technical Efficiency: A Survey of Empirical Application in Agricultural Economics," Agricultural Economics, vol. 7, pp. 185-208, 1992.

[18] T. J. Coelli, "Recent Developments in Frontier Modeling and Efficiency Measurement," Australian Journal of Agricultural Economics, vol. 39, no. 3, pp. 219-45, 1995.

[19] T. J. Coelli, P. Rao, J. C. O’Donnell, and G. E. Battese, "An Introduction to Efficiency and Productivity Analysis," $2^{\text {nd }}$ Edition. Springer, New York, 2005.

[20] M. Weining and W. K. Won, "Productivity Growth, Technological Progress, and Efficiency Change in Chinese Agriculture after Rural Economic Reforms: A DEA Approach," China Economic Review, vol. 8, no. 2, pp. 157-174, 1997.

[21] L. E. Fulginiti and R. K. Perrin, "LDC Agriculture: Non Parametric Malmquist Productivity Indexes," Journal of Development Economics, vol. 53, pp. 373-390, 1997.

[22] C. Umetsu, T. Lekprichakul, U. Chakravorty, "Efficiency and Technical Change in the Philippine Rice Sector: A Malmquist Total Factor Productivity Analysis," American Journal Agriculture Economic, vol. 85, no. 4, pp. 943-963, 2003.

[23] H. S. Nghiem and T. Coelli, "The Effect of Incentive Reforms Upon Productivity: Evidence from the Vietnamese Rice Industry," The Journal of Development Studies, vol. 39, no. 1, pp. 74-93, 2002.

[24] Z. A. Rauzah, "Determining Technical Efficiency among Manufacturing Industries in Malaysia Using Stochastic Frontier Production Function," Journal Productiviti, 2000.

[25] R. Mahadevan, "The Malaysian Path to Sustainable Development in the Manufacturing Sector," ASEAN Economic Bulletin, vol. 28, no. 3, pp. 360-73, 2011.

[26] A. Charnes, W. W. Cooper, and E. Rhodes, "Measuring the Efficiency of Decision Making Units," European Journal of Operational Research, vol. 2, no. 6, pp. 429-444, 1978.

[27] E. G. Tatje and C. A. K. Lovell, "Deregulation and Productivity Decline: The Case of Spanish Savings Banks," European Economic Review, vol. 40, pp. 1281-1303, 1996.

[28] R. Fare, S. Grosskopf, M. Norris, and Z. Zhang, "Productivity Growth, Technical Progress, and Efficiency Changes in Industrialised Countries," American Economic Review, vol. 84, no. 1, pp. 66-83, 1994.

[29] D. W. Caves, L. R. Christensen, and W. E. Diewert, "The Economic Theory of Index Numbers and the Measurement of Input, Output, and Productivity," Econometrica, vol. 50, no. 6, pp. 1393-1414, 1982.

[30] R. Färe, S. Grosskopf, and C. A. K. Lovell, The Measurement of Efficiency of Production, Boston: Kluwer-Nijhoff Publishing, 1985.

[31] L. Simar and P. Wilson, "Productivity growth in industrialized countries," Discussion Paper 9810. Institut de Statistique, Universit'e Catholique de Louvain, Belgium, 1998. 


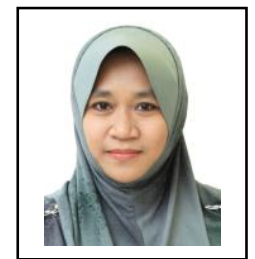

Zarehan Selamat obtained M.Sc. from University Putra Malaysia in the area of Finance. She is a senior lecturer in Faculty of Management Multimedia University, Malaysia. Her main areas of Academic and research interest are Banking and Finance, Islamic Banking, Efficiency and Productivity, Innovation and Technology Acceptance.

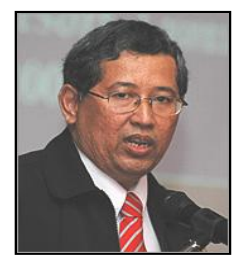

Annuar Md Nasir is a professor in Accounting and Finance Department in University Putra Malaysia. His main areas of research interest are finance and investment analysis. He has published over 80 research articles, co-authored 7 books and supervised more than $20 \mathrm{Ph} . \mathrm{D}$. students of which more than 15 have graduated 